\title{
THE WAY FLOWS OF FOOD PRODUCTS CHANGED IN THE WAKE OF EMBARGO ${ }^{1}$

\author{
N.Shagaida, V.Uzun, E.Shishkina
}

In 2015, export supplies of foodstuffs to Russia from the countries subject to embargo decreased by 66\% compared to 2013. However, the negative effect on the economy of these countries was limited. Total export of foodstuffs in monetary terms fell barely by $7 \%$ and it was redirected to other countries. In the overall export pattern, the share of foodstuffs has even increased.

In August 2014, Russia in response to economic sanctions imposed on certain Russian legal entities and individuals ${ }^{2}$ introduced a ban on a wide range of agricultural products and foodstuffs from EU countries, Norway, USA, Canada, and Australia. The ban was introduced for a year and then extended for another one. At the same time, Russia was a member of EEU and its partners refused to take similar decision.

It was assumed that having lost the Russian market, countries which agricultural products were banned would not be able to find other markets and would suffer losses. Furthermore, the share of Russia in exports of these countries prior to countersanctions (in 2013) constituted on food products $4.8 \%$ and on largest groups reached to $9 \%$ (milk $-9.1 \%$, meat $-7.3 \%$, vegetables $-6.9 \%$, fruits $-8.3 \%$ ). Meanwhile, in Russia's food imports the share of these countries constituted 44\% (at year-end 2015 decreased to 24\%).

In 2015 against 2013, according to Customs Service of Russia, food export to Russia in monetary terms by countries under embargo went down by $66 \%$. However, firstly, total reduction of food export in those countries amounted to barely $7 \%$. Secondly, Export contraction in monetary terms does not signify reduction of export volumes, it is linked with price decline. Thirdly, prices could fall nor so much due to the fact that the market received additional volumes of products, which previously were meant for Russia as owing to decline of costs on energy, credit rates, in other words due to decrease of prime cost of food products production.

Reduction of costs could result in decreased export revenues received by countries under embargo but the profit of farmers could remain the same. The fact that decrease of revenues first of all is linked with price reduction on food products indicates contraction of proceeds from the markets outside Russia where the loss came to $\$ 14.2 \mathrm{bn}$ against $\$ 12.4 \mathrm{bn}$ losses sustained in Russia.

Additionally, export volume growth indicates redirection of flows to other markets (instead of Russia). The produce remained in demand in other countries. For example, the share of food products in exports of countries after introduction of embargo, even amid price reduction, did not decrease and even went up from 8 to $9 \%$ (Table 1).

1 This paper was originally published in Online Monitoring of Russia's Economic Outlook No.6(24).

2 Decree "On Application of Certain Special Economic Measures in Order to Ensure Security of the Russian Federation" № 560 of 6 August 2014. kremlin.ru 
FOOD EXPORTS BY COUNTRIES UNDER EMBARGO, BN USD

\begin{tabular}{|c|c|c|c|c|c|c|c|c|c|}
\hline \multirow{2}{*}{$\begin{array}{l}\text { Product } \\
\text { groups by } \\
\text { OVKED }\end{array}$} & \multicolumn{3}{|c|}{ Total } & \multicolumn{3}{|c|}{ To Russia } & \multicolumn{3}{|c|}{ To other countries } \\
\hline & 2013 & 2014 & 2015 & 2013 & 2014 & 2015 & 2013 & 2014 & 2015 \\
\hline 00 - Total* & 4768.0 & 4817.2 & 4195.6 & 155.1 & 140.2 & 90.0 & 4612.9 & 4677.1 & 4105.5 \\
\hline Total 1-24 & 394.6 & 411.3 & 368.1 & 18.9 & 14.4 & 6.5 & 375.8 & 396.9 & 361.5 \\
\hline Other & 4373.4 & 4405.9 & 3827.5 & 136.2 & 125.7 & 83.5 & 4237.2 & 4280.2 & 3744.0 \\
\hline $\begin{array}{l}\text { Share of } \\
\text { foodstuffs }\end{array}$ & 8 & 9 & 9 & 12 & 10 & 7 & 8 & 8 & 9 \\
\hline
\end{tabular}

* across all export products, 1-24 - food products.

Source: UN Comtrade Database.

The EU example (Annex 1) demonstrates that export volumes registered in 2015 against 2013 did not fell (9 product groups out of 24 by "OKVED" Russian National Classifier of Economic Activities) but in the majority of cases went up (14 groups out of 24). Meanwhile, losses of the EU exports in monetary terms by various reasons amounted to not more than $10 \%$ in current prices. If the prices remained at 2013 level then the EU exporters of food products would have increased their revenues in 2015 as a whole by around $16 \%$ even on condition of continued embargo imposed by Russia (Table 2).

\section{REVALUATION OF TOTAL FOOD EXPORTS FROM EU DURING 2015 IN 2013 PRICES, 2015/2013, \% (ACROSS PRODUCT GROUPS TAKING 5\% AND MORE IN EXPORT PATTERN)}

\begin{tabular}{|c|c|c|c|}
\hline Product group by OKVED & Total & $\begin{array}{l}\text { Including } \\
\text { in Russia }\end{array}$ & $\begin{array}{c}\text { Reference: } \\
\text { food exports } \\
\text { pattern to } \\
\text { Russia in } 2013\end{array}$ \\
\hline Total 1-24 & 115.8 & 38.4 & 100.0 \\
\hline 01 - live animals & 139.5 & 99.6 & 2.1 \\
\hline 02 - meat and edible meat offal & 106.4 & 0.7 & 15.5 \\
\hline $\begin{array}{l}03 \text { - fish and shell fish, scale and } \\
\text { other water invertebrates }\end{array}$ & 103.3 & 23.8 & 8.2 \\
\hline $\begin{array}{l}04 \text { - dairy products; eggs; natu- } \\
\text { ral honey; foods of animal origin }\end{array}$ & 122.4 & 12.1 & 10.4 \\
\hline $\begin{array}{l}07 \text { - vegetables and certain edi- } \\
\text { ble roots and tuber crops }\end{array}$ & 112.9 & 7.5 & 5.0 \\
\hline $\begin{array}{l}08 \text { - edible fruits and nuts; citrus peel } \\
\text { and melon rind }\end{array}$ & 101.6 & 6.4 & 9.3 \\
\hline 21 - various food products & 101.1 & 50.2 & 6.5 \\
\hline 22 - alcoholic and soft drinks and vinegar & 106.6 & 51.6 & 12.6 \\
\hline
\end{tabular}

It is impossible to completely block food supplies originating from the countries under embargo. EEU facilitates the flow of food products to Russia. Refusal of other EEU member states to take similar decision regarding food products embargo. Moreover, the main reason for supply of imported food products via devious paths remains even in the wake of ruble devaluation and growth of domestic prices on imported food products. Export-import operations are very profitable for business. 
Foods products from the countries under embargo none the less come through the EEU market to Russia. How it happens can be seen from an example of several types of vegetables and fruits. Among the EEU countries, Russia is the largest consumer of these products. However, following imposition of food embargo, the volume of vegetables and fruits supplies to EEU market from EU did not decrease but even went up (Table 3).

Table 3

\section{EXPORT OF CERTAIN TYPES OF VEGETABLES AND FRUITS FROM EU TO EEU MINUS RUSSIA, THOUSAND TONS}

\begin{tabular}{|c|c|c|c|c|c|}
\hline & $\begin{array}{l}\text { Code } \\
\text { TN VED }\end{array}$ & 2013 & 2014 & 2015 & $\begin{array}{l}\text { Growth in } \\
2015 \text { against } \\
2013 \text {, times }\end{array}$ \\
\hline 1. Tomatoes & 5702 & 53.3 & 72.6 & 106.4 & 2.0 \\
\hline 2. Cabbage & 0704 & 14.5 & 53.5 & 80.8 & 5.6 \\
\hline 3. Citrus & 0805 & 61.2 & 75.4 & 100.6 & 1.6 \\
\hline $\begin{array}{l}\text { 4. Apples, Pears, } \\
\text { and quince }\end{array}$ & 0808 & 244.8 & 537.3 & 916.2 & 3.7 \\
\hline $\begin{array}{l}\text { 5. Apricots, cher- } \\
\text { ry, sweet cherry }\end{array}$ & 0809 & 36.0 & 88.9 & 197.1 & 5.5 \\
\hline
\end{tabular}

Source: Eurostat.

It is conceivable that increase of supplies growth to EEU could happen due to demand increase in those countries (including Russia). However, this additional demand could not have provoked supplies growth from EU by 2-6 times. For example, according to Belstat data, consumption of vegetables in 2015 in Belorussia moved up barely by 300 grams per person annual and consumption of fruits decreased by $4.5 \mathrm{~kg}$ per person. In 2013, Poland exported to Russia around 700,000 tons of apples. In 2015, approximately the same amount came form Belorussia (according to Belstat report and by 140,000 tons less according to RF Customs Service report) (Table 5).

There was an increase of consumption of vegetables and fruits by $3 \mathrm{~kg}$ per person in Kazakhstan. Theoretically, it boosted demand for imported products bearing in mind natural increase of the population (Table 4). However, additional demand for vegetables and fruits in EEU member-states is significantly lower than the supplies increase of solely two types of vegetables from EU to EEU. Moreover, the vegetables crop growth in Kazakhstan during this period constituted 95,000 tons, i.e. demand growth was satisfied by domestic production. Thus, additional volume of vegetables and fruits arriving from EU to EEU could be consumed solely in Russia.

Table 4

SHIFTS IN CONSUMPTION OF VEGETABLES AND FRUITS IN KAZAKHSTAN AND BELORUSSIA

\begin{tabular}{|c|c|c|c|c|c|c|c|c|}
\hline & \multicolumn{4}{|c|}{ Consumption person/year, kg } & \multirow{2}{*}{\multicolumn{2}{|c|}{$\begin{array}{l}\text { Population, thou- } \\
\text { sand persons }\end{array}$}} & \multicolumn{2}{|c|}{$\begin{array}{l}\text { Shifts in con- } \\
\text { sumption total, } \\
\text { thousand ton }\end{array}$} \\
\hline & \multicolumn{2}{|c|}{ vegetables } & \multicolumn{2}{|c|}{ fruits } & & & \multirow{2}{*}{$\begin{array}{l}\text { vegeta- } \\
\text { bles }\end{array}$} & \multirow{2}{*}{ fruits } \\
\hline & 2014 & 2015 & 2014 & 2015 & 2014 & 2015 & & \\
\hline Belorussia & 86.4 & 86.7 & 71.4 & 66.9 & 9468.2 & 9480.9 & 3.9 & -41.8 \\
\hline Kazakhstan & 86.6 & 89.4 & 60.8 & 63.9 & 17160.1 & 17417.7 & 71.1 & 69.7 \\
\hline Total & & & & & & & 75.0 & 27.9 \\
\hline
\end{tabular}

Sources: Belstat, Komstat of Republic of Kazakhstan. 
Articles surveillance system demonstrates complete inadequacy of information regarding export-import operations. For instance, according to Eurostat (Table 5), in 2015 EU exported to Belorussia 822,000 apples, pears and quince at $\$ 229$ per ton, which is half the average price in EU. In its report Belstat has indicated solely 233,000 tons, which is one fourth of the amount. There are problems in statistics of EEU partner states: the difference in supplies in 2015 registered by Belorussia constituted $26 \%$ of the level registered by Russian customs bodies (Table 5).

Table 5

IMPORTS AND EXPORTS OF APPLES, PEARS, AND QUINCE

\begin{tabular}{|c|c|c|c|c|c|c|c|}
\hline & \multirow{2}{*}{$\begin{array}{l}\text { Source of } \\
\text { informa- } \\
\text { tion }\end{array}$} & \multicolumn{3}{|c|}{$\begin{array}{l}\text { Volume, thou- } \\
\text { sand tons }\end{array}$} & \multicolumn{3}{|c|}{$\begin{array}{c}\text { Average price, } \\
\text { ton/USD }\end{array}$} \\
\hline & & 2013 & 2014 & 2015 & 2013 & 2014 & 2015 \\
\hline EU export to Belorussia & Eurostat & 188 & 453 & 822 & 536 & 409 & 229 \\
\hline $\begin{array}{l}\text { Belorussia imports } \\
\text { from EU }\end{array}$ & Belstat & 202 & 352 & 233 & 508 & 567 & 584 \\
\hline $\begin{array}{l}\text { Belorussia exports } \\
\text { to Russia }\end{array}$ & Belstat & - & - & 676 & - & - & 177 \\
\hline $\begin{array}{l}\text { Russia imports } \\
\text { from Belorussia }\end{array}$ & $\mathrm{CS}$ of RF & 114 & 221 & 536 & 401 & 294 & 170 \\
\hline
\end{tabular}

Sources: Eurostat, Belstat, CS of RF.

Choice of foodstuffs as the main weapon in the sanction war has turned out to be debatable. Countries under the sanctions have lost barely $7 \%$ of their exports' value and mainly due to the price decrease. Price fall on food products by various reasons and not solely owing to additional supply of products, which previously was destined for Russia has led to increased accessibility of food products both inside of these countries and in importers. It is doubtful that embargo could negatively affect the economy of those countries: flows of food products quickly reoriented from the Russian markets to markets of other countries. It was not a big deal owing to a relatively small share of Russia in their exports and availability of a wide export network in other countries. Part of food products all the same reaches the Russian market via EEU because embargo was imposed solely by Russia.

Annex 1

EXPORTS FROM EU COUNTRIES IN MONETARY TERMS AND VOLUME IN 2015 AGAINST 2013

\begin{tabular}{|l|c|c|}
\hline \multicolumn{1}{|c|}{ Products by OKVED } & $\begin{array}{c}\text { In monetary } \\
\text { terms }\end{array}$ & $\begin{array}{c}\text { In weight } \\
\text { terms }\end{array}$ \\
\hline 00 - Total & 0.9 & 1.0 \\
\hline Total 1-24 & 0.9 & 1.2 \\
\hline 01 - live animals & 1.1 & 1.4 \\
\hline 02 - meat and edible meat offal & 0.9 & 1.1 \\
\hline $\begin{array}{l}\text { 03 - fish and shell fish, scale and } \\
\text { other water invertebrates }\end{array}$ & 0.9 & 1.0 \\
\hline $\begin{array}{l}\text { 04 - dairy products; eggs; natu- } \\
\text { ral honey; foods of animal origin }\end{array}$ & 0.9 & 1.2 \\
\hline $\begin{array}{l}05-\text { foods of animal origin not oth- } \\
\text { erwise indexed by name }\end{array}$ & 0.9 & 1.2 \\
\hline $\begin{array}{l}\text { 06 - live trees and other plants; bulbs, } \\
\text { roots and other similar parts }\end{array}$ & 0.9 & 1.0 \\
\hline $\begin{array}{l}\text { 07 - vegetables and some edi- } \\
\text { ble roots and tuber crops }\end{array}$ & 0.8 & 1.1 \\
\hline
\end{tabular}




\begin{tabular}{|c|c|c|}
\hline Products by OKVED & $\begin{array}{l}\text { In monetary } \\
\text { terms }\end{array}$ & $\begin{array}{l}\text { In weight } \\
\text { terms }\end{array}$ \\
\hline $\begin{array}{l}08 \text { - edible fruits and nuts; cit- } \\
\text { rus peel and melon rind }\end{array}$ & 0.8 & 1.0 \\
\hline 09 - coffee, tea, mate, or Paraguay tea and pimento & 1.0 & 1.0 \\
\hline 10 - cereal & 0.9 & 1.3 \\
\hline $\begin{array}{l}11 \text { - products of flour and cere- } \\
\text { als industry; malt; starch; inulin }\end{array}$ & 0.9 & 1.1 \\
\hline $\begin{array}{l}12 \text { - oil seeds and olives; other seeds, } \\
\text { fruits and grain; medicinal }\end{array}$ & 0.9 & 1.0 \\
\hline 13 - shellac; gum, resin and other vegetable juices & 1.0 & 1.2 \\
\hline $\begin{array}{l}14 \text { - vegetative matter for basket- } \\
\text { work production; other products }\end{array}$ & 0.8 & 2.1 \\
\hline $\begin{array}{l}15 \text { - fats and oils of animal and vegetable ori- } \\
\text { gin and products produced from these }\end{array}$ & 0.9 & 1.0 \\
\hline 16 - meat, fish and shellfish and scallops products & 0.8 & 0.9 \\
\hline 17 - sugar and sugar confectionary & 0.9 & 1.1 \\
\hline $18-$ cacao and their products & 1.0 & 1.0 \\
\hline $\begin{array}{l}19 \text { - cereal grain, flour, starch and } \\
\text { dairy products; farinose }\end{array}$ & 1.0 & 1.1 \\
\hline 20 - vegetable, fruit, nuts products & 0.9 & 1.2 \\
\hline 21 - various food products & 0.9 & 1.0 \\
\hline $\begin{array}{l}22 \text { - alcoholic and non-alcohol- } \\
\text { ic beverages and vinegar }\end{array}$ & 0.9 & 1.1 \\
\hline $\begin{array}{l}23 \text { - food-industry waste and remains; } \\
\text { ready-made feed for animals }\end{array}$ & 1.0 & 1.2 \\
\hline 24 - tobacco and industrial tobacco substitutes & 0.8 & 1.0 \\
\hline
\end{tabular}

Sources: Eurostat. 